\title{
Functional and Comparative Bioinformatic Analysis of Expressed Genes from Wheat Spikes Infected with Fusarium graminearum
}

\author{
Warren M. Kruger, ${ }^{1}$ Clara Pritsch, ${ }^{1}$ Shiaoman Chao, ${ }^{2}$ and Gary J. Muehlbauer ${ }^{1}$ \\ ${ }^{1}$ Department of Agronomy and Plant Genetics, University of Minnesota, St. Paul 55108, U.S.A.; ${ }^{2}$ Genetic Resources \\ Conservation Program, University of California, Davis 95616, U.S.A.
}

Submitted 17 September 2001. Accepted 14 January 2002.

Fusarium head blight, caused by the fungus Fusarium graminearum, is a major disease on wheat (Triticum aestivum L.). Expressed sequence tags (ESTs) were used to identify genes expressed during the wheat $-F$. graminearum interaction. We generated 4,838 ESTs from a cDNA library prepared from spikes of the partially resistant cultivar Sumai 3 infected with $F$. graminearum. These ESTs were composed of 2,831 singlet (single-copy transcripts) and 715 contigs (multiple-copy transcripts) for a total of 3,546 nonredundant sequences. Four sets of nonredundant sequences were identified. One set contains numerous, common biotic and abiotic stress-related genes. Many of these stress-related genes were represented by multiple ESTs, indicating that they are abundantly expressed. A second set comprised 16 nonredundant sequences from $F$. graminearum that may be required for pathogenicity. A subset of these fungal genes encodes proteins associated with plant cell wall degradation. A third set of 326 nonredundant sequences had no DNA or amino acid sequence similarity to almost 1 million plant and over 7 million animal sequences in dbEST (as of 22 June 2001). Thus, these 326 nonredundant sequences have only been found in our $F$. graminearum-infected 'Sumai 3' cDNA library. A fourth set of 29 nonredundant sequences was found in our $F$. graminearum-infected wheat and another plant-pathogen interaction cDNA library. Some of these sequences encode proteins that may act in establishing various plant-fungal interactions.

Additional keywords: disease resistance, genomics.

Fusarium head blight (FHB), which is caused primarily by Fusarium graminearum Schwabe [teleomorph Gibberella zeae (Schweinitz) Petch], is a disease of wheat (Triticum aestivum L.) worldwide (Parry et al. 1995). During the 1990s, epidemics of FHB occurred in the Upper Midwest of the United States and an estimated loss of $\$ 1$ billion occurred in 1993 (McMullen et al. 1997a). Infection is initiated in wheat florets at anthesis by $F$. graminearum ascospores. Florets of infected spikes become necrotic and bleached, leading to a reduction in grain yield and quality (McMullen et al. 1997a; Schroeder and Christensen 1963). Trichothecene mycotoxins produced by $F$.

Corresponding author: G. J. Muehlbauer; Fax: 612-625-1268; E-mail: muehl003@tc.umn.edu

Current address of C. Pritsch: Genetica, Facultad de Agronomia, Universidad de la Republica, Garzon 780, Montevideo, Uruguay graminearum, such as deoxynivalenol, accumulate in infected tissues and reduce grain quality (Bai and Shaner 1994; Sutton 1982; Tuite et al. 1990). Currently, planting partially resistant cultivars combined with nonhost crop rotation and fungicide applications are the best control methods (McMullen et al. 1997a, 1997b; Miedaner 1997; Wang and Miller 1988; Wilcoxson et al. 1993).

Although developing FHB-resistant wheat is a primary objective of many breeding programs, there is a limited understanding of the molecular mechanisms involved in the infection of wheat by $F$. graminearum. During the early stages $(<48$ h) of infection of detached barley leaves by $F$. graminearum, hyphal growth occurs without host cell necrosis and the fungus behaves like a biotroph (Bushnell et al. 2000). However, as infection progresses, infected spikes and detached leaf tissue become increasingly necrotic (Bushnell et al. 2000; Kang and Buchenauer 2000a; Pritsch et al. 2000). During the infection of wheat spikes by $F$. culmorum (a Fusarium sp. that also causes FHB), there is a reduction in cell wall components including cellulose, pectin, and xylan, which suggests that $F$. culmorum produces cell-wall-degrading enzymes to assist infection (Kang and Buchenauer 2000a, 2000b). In addition, the trichothecene mycotoxins produced by $F$. graminearum and $F$. culmorum are known to inhibit protein synthesis and may have a role in pathogenesis (Desjardins and Hohn 1997; Kang and Buchenauer 1999). Loss-of-function mutations that prevent trichothecene biosynthesis in $F$. graminearum also reduce fungal virulence (Desjardins et al. 1996; Proctor et al. 1995). Except for the genes involved in trichothecene biosynthesis, no $F$. graminearum genes have been shown to be involved in pathogenesis.

Wheat responds to $F$. graminearum infection by inducing various defenses. In two resistant wheat cultivars, Arina and Frontana, the lignin content in cell walls increased dramatically during infection by $F$. graminearum compared with that in uninoculated plants. In contrast, only a slight increase in lignin was detected in the susceptible cultivar Agent when compared with uninoculated plants (Kang and Buchenauer 2000c). This suggests that lignin restricts fungal colonization. Moreover, infection by $F$. graminearum induces transcript accumulation of several classes of biotic stress-related genes in both partially resistant and susceptible cultivars (Li et al. 2001; Pritsch et al. 2000, 2001). Therefore, the importance of stressrelated gene expression in FHB resistance remains unclear. Given both the complexities and the limited understanding of this plant-pathogen interaction, we felt that functional analysis of a large set of genes that are expressed in response to infection would provide a more complete picture of the wheat $-F$. graminearum interaction. 
Table 1. Functional annotation of contigs with five or more expressed sequence tags (ESTs) that produced BLASTX hits ${ }^{\mathrm{a}}$

\begin{tabular}{|c|c|c|c|}
\hline Genbank accession no. & BLASTX annotation & E value & No. of ESTs \\
\hline BM134651 & 40S ribosomal protein S17 (Arabidopsis thaliana) & $5.00 \mathrm{E}-52$ & 5 \\
\hline BM136009 & $40 \mathrm{~S}$ ribosomal protein $\mathrm{S} 3 \mathrm{a}$ (Oryza sativa) & $1.00 \mathrm{E}-114$ & 5 \\
\hline BM136722 & $40 \mathrm{~S}$ ribosome-associated protein $\mathrm{p} 40$ (Glycine max $)$ & $5.00 \mathrm{E}-97$ & 5 \\
\hline BM140473 & $60 \mathrm{~S}$ acidic ribosomal protein $\mathrm{P} 0$ (Oryza sativa) & $1.00 \mathrm{E}-68$ & 5 \\
\hline BM136113 & 60 S ribosomal protein L18A (Arabidopsis thaliana) & $2.00 \mathrm{E}-88$ & 5 \\
\hline BM137489 & ADP-ribosylation factor (Triticum aestivum) & $4.00 \mathrm{E}-99$ & 5 \\
\hline BM135206 & $\alpha$-Tubulin (Triticum aestivum) & $1.00 \mathrm{E}-126$ & 5 \\
\hline BM135405 & $\beta$-Tubulin 3 (Triticum aestivum) & $1.00 \mathrm{E}-112$ & 5 \\
\hline BM259077 & Chalcone synthase (Secale cereale $)^{\mathrm{b}}$ & $1.00 \mathrm{E}-31$ & 5 \\
\hline BM140574 & Chlorophyll a/b binding protein 2 (Oryza sativa) & $1.00 \mathrm{E}-127$ & 5 \\
\hline BM137496 & Cyclophilin A-2 (Triticum aestivum) & $7.00 \mathrm{E}-78$ & 5 \\
\hline BM138332 & Dormancy-associated protein (Pisum sativum) & $1.00 \mathrm{E}-24$ & 5 \\
\hline BM138490 & Fructose-diphosphate aldolase (Oryza sativa) & $1.00 \mathrm{E}-146$ & 5 \\
\hline BM134846 & Glutathione S-transferase III(a) (Zea mays) ${ }^{\mathrm{b}}$ & $4.00 \mathrm{E}-80$ & 5 \\
\hline BM134484 & Glyceraldehyde-3-phosphate dehydrogenase (Zea mays) & $1.00 \mathrm{E}-164$ & 5 \\
\hline BM137978 & Histone H3 (Triticum aestivum) & $1.00 \mathrm{E}-68$ & 5 \\
\hline BM136577 & Hypothetical protein (Streptomyces coelicolor A3(2)) & $3.00 \mathrm{E}-12$ & 5 \\
\hline BM134888 & L-allo-threonine aldolase homolog (Arabidopsis thaliana) & $1.00 \mathrm{E}-118$ & 5 \\
\hline BM140582 & Lipid transfer protein $(\text { Hordeum vulgare })^{\mathrm{b}}$ & $2.00 \mathrm{E}-45$ & 5 \\
\hline BM140592 & Lipid transfer protein (Triticum turgidum subsp. durum) ${ }^{\mathrm{b}}$ & $1.00 \mathrm{E}-36$ & 5 \\
\hline BM138197 & MTN3-like protein (Arabidopsis thaliana) & $2.00 \mathrm{E}-38$ & 5 \\
\hline BM134430 & Pathogenisis-related protein 1.1 (Triticum aestivum) $^{\mathrm{b}}$ & $1.00 \mathrm{E}-75$ & 5 \\
\hline BM137826 & Superoxide dismutase-4AP (Zea mays) ${ }^{\mathrm{b}}$ & $3.00 \mathrm{E}-74$ & 5 \\
\hline BM135805 & Thaumatinlike protein (Triticum aestivum) ${ }^{\mathrm{b}}$ & $7.00 \mathrm{E}-56$ & 5 \\
\hline BM138338 & Protein with 7 transmembrane domains (Arabidopsis thaliana) & $3.00 \mathrm{E}-74$ & 5 \\
\hline BM136712 & Unknown protein (Arabidopsis thaliana) & $1.00 \mathrm{E}-43$ & 5 \\
\hline BM135005 & Unknown protein (Arabidopsis thaliana) & $2.00 \mathrm{E}-31$ & 5 \\
\hline BM134616 & Unknown protein (Oryza sativa) & 0 & 5 \\
\hline BM135432 & 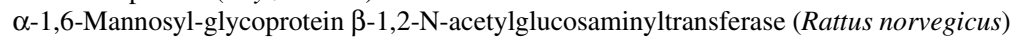 & $9.00 \mathrm{E}-06$ & 6 \\
\hline BM138105 & 23-kDa oxygen evolving protein of photosystem II (Triticum aestivum) & $6.00 \mathrm{E}-73$ & 6 \\
\hline BM136046 & ATP/ADP translocator (Oryza sativa) & $2.00 \mathrm{E}-92$ & 6 \\
\hline BM135996 & Catalase $2{\text { (Hordeum vulgare })^{\mathrm{b}}}$ & 0 & 6 \\
\hline BM135203 & Cytosolic glutamine synthetase (Oryza sativa) & $1.00 \mathrm{E}-143$ & 6 \\
\hline BM135601 & Heat shock $80-2$ (Triticum aestivum $)^{\mathrm{b}}$ & $1.00 \mathrm{E}-125$ & 6 \\
\hline BM135698 & Histone H2A.2 (Triticum aestivum) & $3.00 \mathrm{E}-45$ & 6 \\
\hline BM136957 & 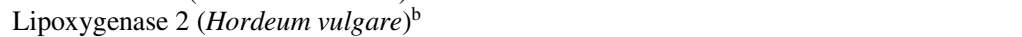 & 0 & 6 \\
\hline BM136916 & Metallothioneinlike protein (Hordeum vulgare) & $4.00 \mathrm{E}-05$ & 6 \\
\hline BM135957 & Mitochondrial ATP synthase 6 KD subunit (Oryza sativa) & $1.00 \mathrm{E}-23$ & 6 \\
\hline BM136224 & Pentameric polyubiquitin (Nicotiana tabacum) & $1.00 \mathrm{E}-129$ & 6 \\
\hline BM137193 & Photosystem II core complex protein (Spinacia oleracea) & $6.00 \mathrm{E}-22$ & 6 \\
\hline BM140532 & Ribosomal protein S8 (Oryza sativa) & $8.00 \mathrm{E}-87$ & 6 \\
\hline BM136453 & Transaldolase (Solanum tuberosum) & $1.00 \mathrm{E}-173$ & 6 \\
\hline BM140554 & Unknown protein (Arabidopsis thaliana) & 4.00E-29 & 6 \\
\hline BM138663 & Cytosolic superoxide dismutase-4AP $(\text { Zea mays })^{\mathrm{b}}$ & $3.00 \mathrm{E}-75$ & 7 \\
\hline BM136408 & Histone $\mathrm{H} 2 \mathrm{~B}$ (Triticum aestivum) & $2.00 \mathrm{E}-43$ & 7 \\
\hline BM135771 & Hypothetical protein (Secale cereale) & $2.00 \mathrm{E}-98$ & 7 \\
\hline BM136229 & Reversibly glycosylated polypeptide (Triticum aestivum) & $1.00 \mathrm{E}-113$ & 7 \\
\hline BM135940 & Translation elongation factor eEF-2 (Beta vulgaris) & $1.00 \mathrm{E}-166$ & 7 \\
\hline BM259047 & Hypothetical protein (Oryza sativa) & $1.00 \mathrm{E}-176$ & 8 \\
\hline BM135977 & Putative integral membrane transporter (Homo sapiens) & 2.00E-07 & 8 \\
\hline BM135358 & Translation elongation factor eEF-1 (Hordeum vulgare) & 0 & 8 \\
\hline BM140534 & Aluminum-induced protein (wali 5) (Triticum aestivum) ${ }^{\mathrm{b}}$ & $1.00 \mathrm{E}-41$ & 9 \\
\hline BM140475 & Cytochrome b5 (Oryza sativa) & $4.00 \mathrm{E}-64$ & 9 \\
\hline BM134462 & Ferredoxin III (Zea mays) & $9.00 \mathrm{E}-52$ & 9 \\
\hline BM134308 & Putative protease inhibitor $(\text { Hordeum vulgare })^{\mathrm{b}}$ & $1.00 \mathrm{E}-41$ & 9 \\
\hline BM140451 & Histone $\mathrm{H} 4$ (Triticum aestivum) & $3.00 \mathrm{E}-39$ & 10 \\
\hline BM135522 & Ribulose 1,5-bisphosphate carboxylase activase (Hordeum vulgare) & 0 & 10 \\
\hline BM136428 & S-adenosylmethionine decarboxylase (Hordeum chilense $\mathrm{x}$ Triticum durum) & $2.00 \mathrm{E}-80$ & 10 \\
\hline BM138494 & Unknown protein (Arabidopsis thaliana) & $3.00 \mathrm{E}-98$ & 10 \\
\hline BM138173 & Lipid transfer protein $(\text { Hordeum vulgare })^{\mathrm{b}}$ & $1.00 \mathrm{E}-45$ & 11 \\
\hline BM135854 & Metallothioneinlike protein (Hordeum vulgare) & $5.00 \mathrm{E}-08$ & 12 \\
\hline BM137488 & Glyceraldehyde 3-phosphate dehydrogenase (Hordeum vulgare) & 0 & 14 \\
\hline BM137110 & Putative lectin (Hordeum vulgare) & $7.00 \mathrm{E}-15$ & 14 \\
\hline BM138588 & Translation elongation factor eEF-1(Triticum aestivum) & $1.00 \mathrm{E}-175$ & 14 \\
\hline BM134417 & $\alpha$-Tubulin 2 (Hordeum vulgare) & 0 & 15 \\
\hline BM135585 & $\mathrm{H}(+)$-transporting ATPase (Zea mays) & 0 & 17 \\
\hline
\end{tabular}

\footnotetext{
${ }^{a}$ Functional annotation and corresponding E value for the highest scoring BLASTX hit for the consensus sequence for each contig is listed. The GenBank accession number corresponds to the most $5^{\prime}$ sequence in each contig and the number of EST components in each contig is also listed. Two contigs had no BLASTX hits and were not included in this table.

${ }^{\mathrm{b}}$ Genes whose expression is associated with stress responses.
} 
Expressed sequence tags (ESTs) offer an efficient approach to identify and analyze thousands of plant genes expressed during plant development and in response to a variety of conditions (Gyorgyey et al. 2000; White et al. 2000; Yamamoto and Sasaki 1997). In addition, ESTs have been used to analyze genes expressed by fungal pathogens of plants (Keon et al. 2000; Qutob et al. 2000; Waugh et al. 2000). The ability to examine thousands of ESTs is an efficient way of analyzing expressed sequences from the genomes of wheat and F. graminearum that is especially helpful when you consider that the genome size of wheat is approximately 16,000 Mbp (Arumuganathan and Earle 1991). The genome of F. graminearum is estimated to be $40 \mathrm{Mbp}$, and it is believed to encode approximately 9,200 genes, which is similar to the number of genes in Neurospora crassa (H. C. Kistler, personal communication). The development of EST databases provides a resource for transcript profiling experiments and in silico studies of gene expression (Mekhedov et al. 2000; Schenk et al. 2000). An EST database generated from wheat spikes infected with $F$. graminearum will provide information about expressed genes that is required to develop an initial framework for the interaction between wheat and the fungus.

In this article, we describe both functional and comparative analyses of genes that are expressed during the wheat $-F$. graminearum interaction. As outlined by Michelmore (2000), we have conducted in silico analyses of large datasets of ESTs as the first step in identifying sets of genes expressed during FHB that will be used in future experimentation. We prepared a cDNA library using mRNA isolated from spikes of the partially resistant cultivar Sumai 3 infected with $F$. graminearum. 'Sumai 3' exhibits resistance to spread of infection in the spike, which is referred to as type II resistance (Schroeder and Christensen 1963). We generated and analyzed 4,838 ESTs from this library and identified four sets of genes: (i) biotic and abiotic stress-related genes that are involved in general host responses to pathogen infection, (ii) F. graminearum genes that may be required for pathogenicity, (iii) genes that have not been sequenced from other wheat cDNA libraries and all other ESTs from plants and animals deposited in GenBank, and (iv) genes that are only expressed in plant-fungal interactions.

\section{RESULTS}

\section{cDNA library and nonredundant sequences.}

We prepared a cDNA library using pooled mRNA from ' $\mathrm{Su}$ mai 3' (type II resistance) spikes spray inoculated with $F$. graminearum and sampled at $0,6,12,24,36$, and $48 \mathrm{~h}$ after inoculation. The titer of the primary library was approximately $2 \times 10^{6} \mathrm{PFU}$, and the average cDNA insert size was found to be approximately $1 \mathrm{~kb}$. Single-pass, $5^{\prime}$-end sequencing of 4,838 random cDNA clones was conducted in two batches. We processed a first batch of 89 sequences in a pilot experiment and a much larger set of 4,749 sequences was processed in Olin Anderson's laboratory (United States Department of Agriculture-Agricultural Research Service [USDA-ARS], Albany, CA, U.S.A.). In the first batch of 89 ESTs, the sequence length ranged from 104 to 406 bases, with an average read length of 314 bases. The average phred score for these processed ESTs was 37 and ranged from 12 to 56 . In the second batch of 4,749 ESTs, the sequence length ranged from 100 to 760 bases, with an average read length of 431 bases. The average phred score for these processed ESTs was 35 and ranged from 10 to 55. A sequence read of $100 \mathrm{bp}$ was required for continued analysis.

Redundant ESTs, those with homologous overlapping sequences, were grouped into contigs using the phragment assembly program (PHRAP) with a minimum match of 40 and a minimum score of 80 . Each contig has a consensus sequence and each EST in a contig is a copy of a transcript from the same gene. A nonredundant set of 3,546 sequences was compiled that comprised 2,831 singletons (single-copy sequences) and 715 contigs (multiple-copy sequences). There were 68 contigs that contained five or more ESTs; the largest consisted of 17 ESTs. Contigs with five or more ESTs were regarded as abundant gene transcripts (Table 1). Approximately 64\% (460 of 715) of the contigs contained two ESTs and, together with the singletons, over two-thirds $(68 \%)$ of the ESTs were from low-copy gene transcripts $(3,297$ of 4,838).

\section{Functional annotation.}

To assign functions to the proteins encoded by the nonredundant sequences, the DNA sequences were translated into their corresponding amino acid sequences and searched against the nonredundant GenBank protein database using the BLASTX algorithm. A maximum probability threshold for a sequence match was set to $10^{-5}$. The nonredundant sequences were categorized into one of eight gene classes based on their BLASTX annotation (Fig. 1). A nonredundant sequence with a sequence match probability $>10^{-5}$ did not meet the threshold and was placed in the unknown functional category. Nonredundant sequences that had BLASTX hits to amino acid sequences with no known function were classified as miscellaneous. All nonredundant sequences with a BLASTX hit to a fungal protein were assumed to be fungal genes. Nonredundant sequences with BLASTX matches to proteins with known functions were assigned to one of five functional gene classes: structural, metabolism, regulatory, secondary metabolism, and protein synthesis and modification. In this manner, we created a functional inventory of the 3,546 expressed genes in our database, which represents a partial catalog of genes expressed in wheat spikes at $0,6,12,24,36$, and $48 \mathrm{~h}$ after inoculation with $F$. graminearum. The structural and metabolic genes had the largest number of genes encoding proteins with known function and together accounted for $23 \%$ of all nonredundant sequences. The number of genes encoding proteins of unknown function was the largest and contained approximately $49 \%(1,723$ of 3,546$)$ of the nonredundant sequences.

The contigs represent the most abundant transcripts, which makes them a likely set of genes that are abundantly expressed during infection. Almost 21\% (150 of 715) of the contigs were found to encode proteins with unknown functions. The most common functions found among contigs made up of five or more ESTs were structural proteins, metabolic enzymes, or common stress-related proteins (Table 1). Among the set of contigs containing five or more ESTs, only two out of 68 contigs did not produce BLASTX annotations and were considered to encode proteins with unknown function.

\section{Biotic and abiotic stress-related genes.}

To identify putative stress-related genes, we searched our database for nonredundant sequences encoding proteins with functions that may be associated with the response of plants to infection with fungi (including $F$. graminearum), viruses, bacteria, or nematodes (Bowles 1990; Cutt and Klessig 1992; Dixon and Lamb 1990; Hammond-Kosak and Jones 1996), or under abiotic stress (Ristic et al. 1998; Sabehat et al. 1998). This search identified 312 nonredundant sequences encoding phenylpropanoid pathway enzymes, oxygen metabolism and redox enzymes, pathogenesis-related proteins, and several other defense- and stress-related proteins. We found multiple types or contigs for many of these 312 nonredundant sequences. Types are defined as sequences with similar BLASTX annotations, but which did not group into a contig (discussed below). We identified 167 of these 312 nonredundant sequences that are commonly found to be upregulated in 
plants under biotic and abiotic stress (Table 2). This set of nonredundant sequences consists of 29 classes and comprise 327 ESTs (Table 2).

Many of the sequences encoding biotic stress-related proteins, like lipid transfer proteins and pathogenesis-related protein 1, were detected as contigs with five or more ESTs (Table 1). Other biotic stress-related genes, like those encoding $\beta$-1,3-glucanase and thaumatinlike protein, were expressed as multiple types, 10 and 4, respectively (Table 2). Similarly, sequences that encode proteins associated with plant responses to abiotic stress also occurred as contigs with five or more ESTs (e.g., some aluminum-induced and heat-shock proteins) (Table 1), or as abundant types (e.g., cold acclimation protein and drought-induced protein) (Table 2). The relatively high representation of stressrelated gene transcripts suggests that they are abundantly expressed during the wheat $-F$. graminearum interaction.

\section{Fungal genes.}

A little over $2 \%$ ( 86 of 3,546 ) of the nonredundant sequence set was found to encode fungal proteins (Fig. 1). Nonredundant sequences with BLASTX annotations to proteins from any fungal species were assumed to be $F$. graminearum genes. Initially, we identified $60 \mathrm{~F}$. graminearum genes based on their BLASTX annotations to proteins from fungal species in GenBank. An additional 26 sequences were determined to be of fungal origin based on their sequence redundancy, using PHRAP (minimum match of 40 and minimum score of 80 ), to $8,727 F$. graminearum ESTs generated from three cDNA libraries (made available through the consent of H. C. Kistler, F. Trail, and J. Xu). These libraries were prepared using mRNA from $F$. graminearum grown using one of three different conditions: carbon-starved, nitrogen-starved, or perithecium-forming media. These $F$. graminearum ESTs are publicly available through the U.S. Wheat and Barley Scab Initiative Website link to the $F$. graminearum EST database at Purdue University.

Almost all the fungal genes ( 82 of 86 ) were low-copy gene transcripts (68 singletons and 14 contigs with two ESTs). One fungal gene was found to be an abundant transcript composed of six ESTs and was similar to a rat gene that encodes $N$-ace- tylglucosaminyltransferase (Table 1). Sixty-four expressed $F$. graminearum genes were common to the infected and cultured libraries. Most of these were in two gene classes; 25 (39\%) encoded structural proteins and $21(33 \%)$ encoded proteins with unknown function. Using PHRAP (minimum match of 40 and minimum score of 80), we identified 22 fungal sequences that were not redundant with any of the $F$. graminearum ESTs generated from the fungal cultures. Thus, from this comparative search, we were able to identify genes that were not expressed by $F$. graminearum in culture and are candidates for "pathogenesis-specific" expression.

Of the $22 F$. graminearum gene candidates for pathogenesisspecific expression, 9 did not produce hits in a sequence similarity search of dbEST using the BLASTN algorithm. Six of the pathogenesis-specific gene candidates produced dbEST hits to sequences from at least one fungal culture cDNA library and were not considered to be pathogenesis-specific. The seven remaining pathogenesis-specific gene candidates produced dbEST hits to sequences derived from either a Magnaporthe grisea appressorium stage cDNA library, a transgenic $F$. sporotrichioides strain overexpressing the Trilo trichothecene pathway gene, or a different wheat- $F$. graminearum infected library. Sequences derived from these libraries may be associated with fungal pathogenicity; therefore, these sequences were still considered to be candidates for pathogenesis-specific expression. Thus, we have identified a subset of $16 \mathrm{~F}$. graminearum genes whose expression may be pathogenesis specific (Table 3). Several were genes that encode enzymes associated with the degradation of plant cell wall components, including xylanase, alkaline proteinase, and $\beta$-D-galactosidase, and with a "cutinase-binding protein" that regulates the expression of cutinase. A gene encoding trichodiene oxygenase, which is the first oxygenation step in the trichothecene biosynthetic pathway, also was found. However, several genes encoding proteins with functions unlikely to have a role in pathogenicity were found (e.g., proteasome subunits and general metabolism enzymes). We also identified three fungal genes encoding an NADP-specific glutamate dehydrogenase, a CCR4 (carbon

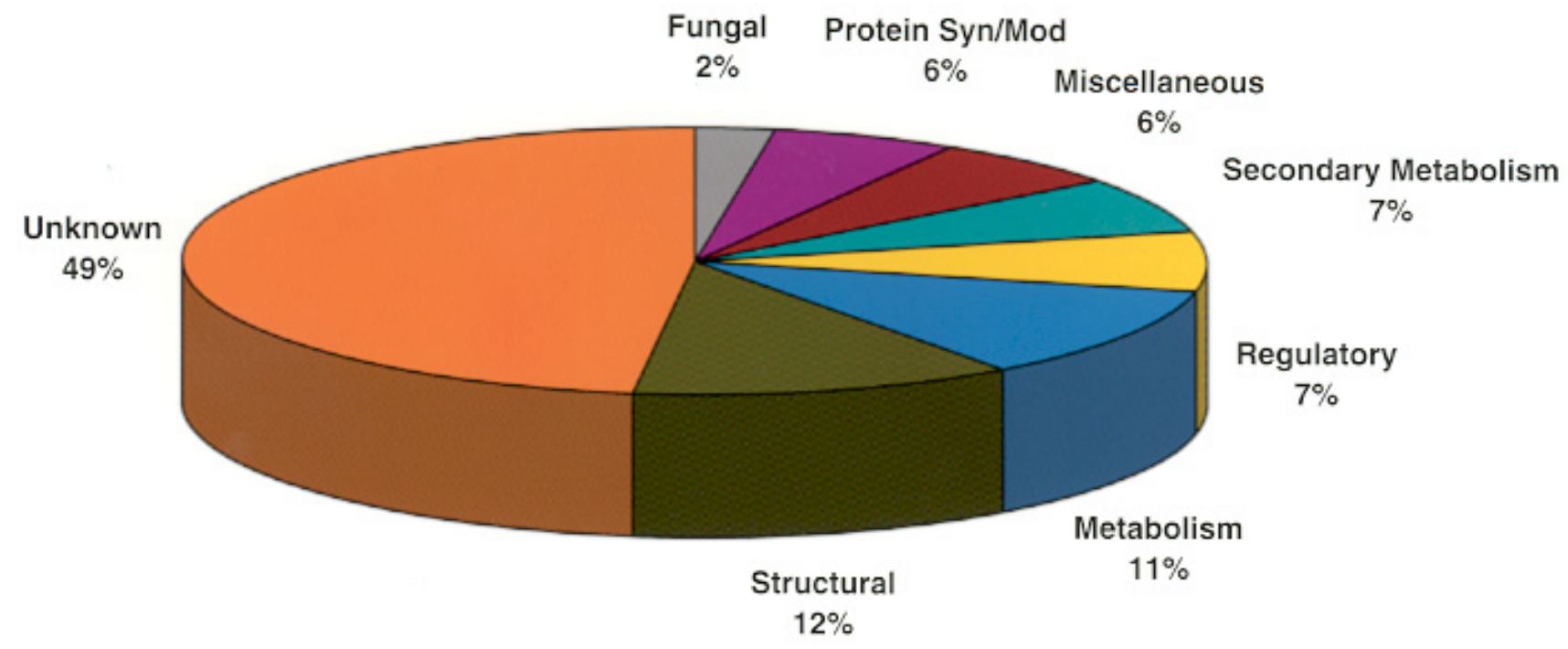

Fig. 1. Percentage of 3,546 nonredundant sequences grouped as fungal, genes of unknown function, and plant genes classified in six categories by function. Metabolism: proteins with a defined metabolic function like those involved in energy, redox, lipid, or carbohydrate metabolism; Structural: membranebound, cytoskeleton, and ribosomal proteins; Secondary metabolism: phenylpropanoid, pathogenesis-related, and flavanoid and lignin biosynthetic proteins; Regulatory: included MAP kinases, transcription factors, and proteins that are associated with development or cell cycle control; Protein synthesis and modification: translation factors, tRNA ligases, and protein kinases and hydrolases; Miscellaneous: proteins with no discernable function. Expressed sequence tags (ESTs) that did not produce a BLASTX hit, or with hits with E values greater than $10^{-5}$, were considered to have an unknown function. Fungal genes were made up of ESTs that had BLASTX hits to fungal proteins and those that produced sequence matches to any of the over 8,727 Fusarium graminearum ESTs made available to us by H. C. Kistler, F. Trail, and J. Xu. 
catabolite repressor) protein, and a hexose transporter protein whose expression may be regulated by the presence of glucose (Hawkins et al. 1989; Malvar et al. 1992; Yu et al. 2000). However, these proteins do not have an obvious role in pathogenesis.

\section{Nonredundant sequence sspecific}

to our $\boldsymbol{F}$. graminearum-infected 'Sumai 3' cDNA library.

To identify expressed gene sequences that were specific to our F. graminearum-infected 'Sumai 3' spike cDNA library, we looked for nonredundant sequences that had no sequence similarity to any of the 74,415 wheat ESTs in dbEST using the BLASTN algorithm. The primary sources for the wheat ESTs in dbEST were the National Science Foundation-funded, U.S. Wheat EST Project and the International Triticeae EST Cooperative. These ESTs were generated from cDNA libraries prepared using different tissues, growth stages, and conditions from several species of Triticum and Aegilops. Of particular interest were approximately 16,700 wheat spike ESTs. These were generated from cDNA libraries prepared using mRNA from one pre- and two post-anthesis spike cDNA libraries and from one heat-stressed spike cDNA library. In addition, there were 727 ESTs generated from a different cDNA library prepared from $F$. graminearum-infected 'Sumai 3' spikes sampled at $24 \mathrm{~h}$ after inoculation. From our 3,546 nonredundant sequences, 2,503 produced a sequence match $\left(P \leq 10^{-5}\right)$ to wheat ESTs in dbEST, whereas almost 30\% (1,049 of 3,546) did not. It is possible that an EST with the same BLASTX annotation as another wheat EST does not produce a sequence match because it is derived from nonoverlapping regions of the same gene transcript.

Over $67 \%$ (707) of the 1,049 library-specific genes encoded proteins of unknown function. These 707 genes compose $41 \%$ of the 1,723 genes in the original unknown class. Over $80 \%$ of the fungal genes and between 10 and $28.5 \%$ of the known genes from the original classification (metabolism, secondary metabolism, regulatory, protein synthesis and modification, structural, and miscellaneous) were found to be library-specific. There were 10 library-specific contigs with three or more EST components; the largest has five ESTs and was found to encode a thaumatinlike protein. Among the other proteins encoded by the library-specific genes were transcription factors, mitogen-activated protein (MAP) kinases, DNA polymerases, and cell cycle regulatory proteins that may be associated with pathogen recognition, signal transduction, and the induction of defense-related gene expression.

Using the BLASTN and TBLASTX algorithms $\left(P \leq 10^{5}\right)$, we found 326 nonredundant sequences that had no sequence matches to any of the almost 1 million plant and the over 7.2 million animal ESTs in dbEST (data not shown). Almost $97 \%$ (315 of 326) of these expressed genes encode proteins with unknown functions. Furthermore, although they were not found in other cDNA libraries, 30 of these genes were found as contigs, three of which contained three ESTs. Thus, we have putatively identified a subset of what appear to be rarely transcribed, library-specific genes that are expressed during the wheat $-F$. graminearum interaction.

\section{Genes specific to plant-fungal interactions.}

We performed a comparative search of dbEST, using the BLASTN algorithm $\left(P \leq 10^{-5}\right)$, with the ESTs from our $F$. graminearum-infected 'Sumai 3' cDNA library and found 29 genes that produced matches only to sequences from other plant-fungal interactions (Table 4). The matching sequences were from six cDNA libraries with approximately (i) 730 ESTs from 'Sumai 3' spikes infected with $F$. graminearum sampled at $24 \mathrm{~h}$ after inoculation (hai); (ii) 6,200 ESTs from resistant wheat leaves infected with leaf rust sampled at 24 hai with Puccinia triticina; (iii) 9,600 ESTs from seedlings of two different resistant barley lines inoculated with Blumeria (Erysiphe) graminis; (iv) 11,000 ESTs from juvenile-resistant, 2week-old anthracnose-infected sorghum leaves 48 hai with Colletotrichum graminicola; and (v) 7,400 ESTs from Medicago truncatula roots harvested at 10, 17, 22, 31, and 38 days postinoculation with the arbuscular mycorrhizal fungus Glomus versiforme. Thus, we have identified a set of 29 genes that are expressed in at least one resistant plant-fungal interaction.

Among these 29 genes, 11 had no BLASTX hit, 3 had a BLASTX hit to proteins of unknown function, and 15 encode proteins that do not have an obvious defense-related function. Only two genes occurred as multiple-copy transcripts, a gene encoding a lectin and a peptide transporter found as contigs containing 14 and 4 ESTs, respectively. The rest were lowcopy (singletons or two-component contigs) gene transcripts (Table 4). Two genes that encode kaurene synthase, which is involved in gibberellin synthesis, were the only genes encoding more than one type in this set. The 29 genes were grouped into four subsets according to the plant-fungal interactions in which they are expressed. A subset of seven genes was only expressed in wheat spikes infected with $F$. graminearum and may be specifically expressed during the wheat $-F$. graminearum interaction. Three subsets of 22 genes were expressed in wheat spikes infected with $F$. graminearum and in one other plantfungal interaction. Within these subsets, we found four genes that were expressed in the wheat $-F$. graminearum and wheat $-P$.

Table 2. Classes of biotic and abiotic stress-related genes found in our database

\begin{tabular}{|c|c|c|}
\hline Functional class & $\begin{array}{l}\text { No. of } \\
\text { types }\end{array}$ & $\begin{array}{l}\text { No. of } \\
\text { ESTs }\end{array}$ \\
\hline \multicolumn{3}{|l|}{ Biotic stress } \\
\hline Polygalacturonase inhibitor & 1 & 1 \\
\hline Cinnamyl alcohol dehydrogenase & 2 & 2 \\
\hline Osmotinlike protein & 1 & 2 \\
\hline Avr9 elicitor response protein & 2 & 2 \\
\hline Hypersensitive-induced protein & 1 & 4 \\
\hline Chalcone synthase & 1 & 5 \\
\hline O-methyltransferase & 5 & 5 \\
\hline Chitinase & 6 & 9 \\
\hline Pathogenesis-related protein 1 & 3 & 9 \\
\hline Thaumatinlike protein & 4 & 10 \\
\hline Lipoxygenase & 5 & 10 \\
\hline Phenylalanine ammonia-lyase & 6 & 11 \\
\hline Catalase & 5 & 14 \\
\hline Superoxide dismutase & 3 & 15 \\
\hline Proteinase inhibitor (defensin) & 7 & 17 \\
\hline$\beta$-1,3-Glucanase & 10 & 18 \\
\hline Glutathione S-transferase & 16 & 23 \\
\hline Peroxidase & 22 & 34 \\
\hline Lipid transfer proteins & 19 & 57 \\
\hline \multicolumn{3}{|l|}{ Abiotic stress } \\
\hline Chilling-induced protein & 1 & 1 \\
\hline Stress-related protein & 1 & 1 \\
\hline Submergence-induced protein $2 \mathrm{~A}$ & 1 & 2 \\
\hline Wound-induced protein & 2 & 2 \\
\hline Dehydration-induced protein & 2 & 3 \\
\hline Cold acclimation protein & 2 & 4 \\
\hline Low temperature and salt responsive protein & 3 & 4 \\
\hline Drought-induced protein & 3 & 5 \\
\hline Wheat aluminum-induced proteins & 7 & 21 \\
\hline Heat-shock protein & 26 & 36 \\
\hline
\end{tabular}

a No. of types $=$ number of nonredundant sequences with the same or very similar BLASTX annotations, but which did not group into a contig (discussed in text). These genes, which encode proteins associated with plant responses to biotic or abiotic stress, are likely to have types that are abundantly expressed in response to infection.

${ }^{\mathrm{b}} \mathrm{ESTs}=$ expressed sequence tags. 
triticina interactions. Another 14 genes were expressed in the wheat $-F$. graminearum and barley-B. (Erysiphe) graminis interactions. The remaining four genes were expressed in the wheat $-F$. graminearum and sorghum-anthracnose interactions.

\section{DISCUSSION}

We examined 4,838 ESTs from a cDNA library prepared using mRNA from 'Sumai 3' wheat spikes sampled at six time points, including uninoculated $(0 \mathrm{~h})$, during the first 48 hai with $F$. graminearum. Descriptions of $F$. graminearum and $F$. culmorum infections indicate that, during this time interval, extensive hyphal growth occurs without host cell necrosis (Bushnell et al. 2000; Kang and Buchenauer 2000a; Pritsch et al. 2000). Furthermore, penetration of host cells was reported to occur at 36 hai (Kang and Buchenauer 2000a). We used functional and comparative bioinformatic tools to identify sets of expressed genes that provide insight into the molecular mechanisms of the wheat $-F$. graminearum interaction. The ESTs were arranged into a functional database composed of 3,546 nonredundant, wheat and $F$. graminearum sequences. Simple and more advanced comparative searches of our database and other EST databases were made to identify four subsets of expressed genes: (i) biotic and abiotic stress-related genes, (ii) genes putatively required by $F$. graminearum for pathogenicity, (iii) genes that have not been sequenced from wheat and all other plant and animal ESTs in dbEST, and (iv) genes that are putatively only expressed in plant-fungal interactions.

\section{Stress-related gene expression in wheat spikes infected with $F$. graminearum.}

Simple searches of our database, based on gene function, were used to identify genes encoding pathogenesis-related (PR) proteins. Genes encoding PR-1, $\beta$-1,3-glucanase, chitinase, and thaumatinlike proteins were found as either multiplecopy transcripts (contigs) or multiple types in our EST database (Table 2). The abundance of an EST is an approximation of relative gene expression; this suggests that these defense-related genes were abundantly expressed during infection of wheat by $F$. graminearum (Audic and Claverie 1997; Ewing et al. 1999; Mekhedov et al. 2000; Rafalski et al. 1998; White et al. 2000). This is in agreement with a previous study by Pritsch and associates (2000) that showed that infection of wheat spikes with $F$. graminearum results in the induction of a large set of biotic stress-related genes, including PR-1, PR-2, PR-3, PR-4, PR-5, and peroxidase in both the type II resistant cv. Sumai 3 (resistance to fungal spread in the spike) and the susceptible cv. Wheaton. Their results also showed earlier and greater accumulation of PR-4 and PR-5 transcripts in resistant genotypes compared with susceptible genotypes (Pritsch et al. 2000). Another study by Li and associates (2001) showed that expression of biotic stress-related genes encoding PR-2 and PR-3 was earlier and greater in 'Sumai 3' than a susceptible 'Sumai 3' mutant. Further studies showed a systemic induction of biotic stress-related genes encoding PR-1, PR-3, PR-5, and peroxidase (Pritsch et al. 2001).

In addition to genes encoding PR proteins, we also identified ESTs that correspond to other types of stress-related genes (e.g., phenylpropanoid pathway enzymes, oxygen metabolism enzymes, lipid transfer proteins, and the cellular protectant glutathione S-transferase). Phenylpropanoids and their derivatives have been implicated in plant defenses against both biotic and abiotic stress (Dixon and Paiva 1995). In response to infection by $F$. culmorum, the accumulation of lignin, a product of phenylpropanoid metabolism, occurred to a greater extent in two resistant cultivars than in a susceptible cultivar of wheat compared with uninoculated plants (Kang and Buchenauer 2000c). There is evidence to suggest that flavonoids, which are synthesized from phenylpropanoids, exhibit antifungal properties against Fusarium species (Silva et al. 1998; Skadhauge et al. 1997). Some stress-related genes from our EST database also were identified among ESTs from other stress conditions (biotic or abiotic). This suggests that some stress-related genes identified in this study may be induced by a variety of stresses. For example, the expression of HSP70, a type of heat-shock protein identified in our database, is upregulated in response to heat stress (Sung et al. 2001) and also by pathogen infection (Byth et al. 2001; Vaghchhipawala et al. 2001).

Our data, together with other published findings, show that $F$. graminearum infection of wheat spikes results in the expression of several classes of biotic and abiotic stress-related genes. These data suggest that a pathogen-induced, signal transduction pathway operates in the wheat $-F$. graminearum interaction. The expression of biotic and abiotic stress-related genes may result in a reduction of FHB severity in wheat, but a definitive relationship between type II FHB resistance and stress-related gene expression has not been established.

\section{Fungal genes with potential pathogenicity functions.}

Little is known about the genes that are expressed in $F$. graminearum during infection of wheat spikes. In this study, we identified $86 \mathrm{~F}$. graminearum genes that were expressed during infection. We would expect high sequence correlation between $F$. graminearum sequences; therefore, we used PHRAP (minimum match 40, minimum score 80 ) and found that approximately $19 \%$ (16 of 86 ) of the F. graminearum sequences were not redundant to 8,727 ESTs generated from three different cultured $F$. graminearum cDNA libraries. Furthermore, these sequences did not produce BLASTN matches $\left(P \leq 10^{5}\right)$ in dbEST to ESTs derived from cDNA libraries that were in any way associated with fungal pathogenesis. Thus, the findings from the sequence similarity searches suggest that these $16 \mathrm{~F}$. graminearum genes might be specifically expressed during pathogenesis (Table 3 ).

Of the $16 F$. graminearum genes specifically expressed during infection, we identified a set that encodes proteins associated with plant cell wall degradation or modification, including four xylanase types, a $\beta$-D-galactosidase, an alkaline proteinase, and a "cutinase binding protein". The identification of these genes for pathogenesis-specific expression fits with a probable biological role for their corresponding proteins in infection of wheat by F. graminearum. Cell walls of grasses (Poaceae family) are composed primarily of large amounts of cellulose and xylan with a small amount of pectin (Carpita and Gibeaut 1993 ) and $F$. graminearum would have to degrade the plant cell walls to penetrate wheat cells. There is some descriptive evidence to support this idea. Wheat spikes infected with $F$. culmorum exhibit reduced cellulose, xylan, and pectin content in cell walls located near the growing hyphal tip, which suggests that the fungus is producing enzymes to degrade these compounds (Kang and Buchenauer 2000a, 2000b). In addition, alkaline proteinase is putatively involved with the degradation of plant cell wall components (Carlile et al. 2000; Sreedhar et al. 1999). Histological observations showed that $F$. graminearum exhibits subcuticular growth, indicating that the fungus may break down the cuticle layer (Pritsch et al. 2000). A variety of phytopathogenic fungi, including other Fusarium spp., express genes encoding cuticular and cell wall degrading enzymes (Crawford and Kolattukudy 1987; Giesbert et al. 1998; Heiler et al. 1993; ten Have et al. 1998). Furthermore, the cutinase binding protein activates expression of cutinase by binding to a cis-element in the cutinase gene promoter ( $\mathrm{Li}$ and Kolattukudy 1997). Moreover, the enzyme $\beta$-D-galactosidase 
has been shown to modify plant cell wall pectin (Ali et al. 1995). Therefore, the identification of $F$. graminearum genes from our EST database that encode enzymes that are associated with cuticular and cell-wall-degradation, or proteins that regulate their expression, is consistent with the idea that these enzymes are involved with pathogenesis.

One of the infection-specific $F$. graminearum genes encodes for trichodiene oxygenase, which catalyzes the first oxygenation step in the trichothecene pathway (Trapp et al. 1998). The trichothecenes deoxynivalenol, 3-acetyldeoxynivalenol, and 15-acetyldeoxynivalenol have been implicated in $F$. graminearum pathogenesis, phytotoxicity, and the induction of apoptosis in eukaryotic cell cultures (Kang and Buchenauer 1999; Miller and Ewen 1997; Shifrin and Anderson 1999). A loss-offunction mutation in the Tri5 gene (Tri5 encodes the first enzyme in the trichothecene biosynthetic pathway) of $F$. graminearum results in the lack of trichothecene production and reduces the virulence of $F$. graminearum on wheat (Desjardins et al. 1996; Proctor et al. 1995). Moreover, the concentration of deoxynivalenol in $F$. culmorum-infected wheat chaff and kernels was lower in a resistant cultivar than in a susceptible cultivar (Snijders and Krechting 1992). The trichothecenes deoxynivalenol, 3-acetyldeoxynivalenol, and 15 -acetyldeoxynivalenol can be detected in hyphae growing on the lemma and ovary surfaces of wheat as early as 36 hai with F. culmorum (Kang and Buchenauer 1999). Therefore, the identification of a trichothecene biosynthetic pathway gene transcript within 48 hai is consistent with the timing of trichothecene accumulation and with the possible role of these toxins in pathogenesis.

Because they do not have functions obviously associated with pathogenicity, it is not possible to propose a specific role in pathogenesis for the proteins encoded by fungal genes that are not specifically expressed during pathogenesis. However, we cannot overlook the possibility that some of these genes encode proteins that may be associated with pathogenicity. One of the $F$. graminearum genes was a contig with six EST components (Table 1). The cDNA library used in this study was prepared using tissue sampled from spikes at $0,6,12,18$, 24, 36, and 48 hai. Therefore, the majority of the transcripts should be of plant origin, and it was unexpected to find a fungal sequence among the abundant gene transcripts, which suggests that it was abundantly expressed. The consensus sequence for this contig was putatively identified to encode $N$ - acetylglucosaminyl transferase, which is involved in the synthesis of complex glucans (D'Agostaro et al. 1995). However, the exact role that this enzyme plays in fungal development or infection is unknown.

\section{Rarely expressed genes}

from the wheat-F. graminearum library.

Our ESTs were not generated from a subtracted cDNA library; therefore, we wanted to know which of the wheat genes were expressed in response to infection and which were expressed as part of normal development. We identified 1,049 nonredundant sequences from our database of 4,838 ESTs that had no sequence similarity to any of the 74,415 wheat EST submissions in dbEST. Library-specific genes were distributed among all the functional classes that were established for the nonredundant sequences. Over $80 \%$ of the 86 fungal genes were found among these library-specific sequences, and we expect that more ESTs might be derived from $F$. graminearum. Therefore, we have identified a large set of what appear to be rarely expressed wheat gene transcripts and some $F$. graminearum transcripts that were found in our cDNA library made from 'Sumai 3' infected with $F$. graminearum. Two-thirds of these 1,049 genes encode proteins with unknown functions. Of particular interest among the genes with known functions are those encoding proteins that may be implicated in pathogen recognition, signal transduction, and the induction of defenserelated gene transcription (e.g., MAP and protein kinases, transcription factors, and resistance gene analogs) (Bent 1996; Somssich and Hahlbrock 1998; Torii 2000; van der Biezen and Jones 1998; Yang et al. 1997).

A subset comprising $31 \%$ (326 of 1,049) of the library-specific genes did not produce sequence matches $\left(P \leq 10^{5}\right)$ in dbEST with the BLASTN or TBLASTX algorithms. In searching different databases in GenBank, we found some genes with a functional annotation but no dbEST hit (discussed below). Most (approximately 97\%) of these genes encode proteins with unknown functions and their role in the wheat $-F$. graminearum interaction is uncertain. Our interest in these genes is that, except for our cDNA library, they were not sequenced among approximately 1 million plant ESTs in GenBank that were generated from a wide diversity of growth stages and conditions as well as different biotic and abiotic stress conditions. This includes large numbers of ESTs from several plant species, including approximately 172,648 Gly-

Table 3. Fusarium graminearum genes specific to infected wheat spike tissue ${ }^{\mathrm{a}}$

\begin{tabular}{|c|c|c|}
\hline Genbank accession no. & Functional annotation & E value \\
\hline BM138413 & $\beta$-D-galactosidase (Kluyveromyces lactis) ${ }^{\mathrm{b}}$ & $3.00 \mathrm{E}-32$ \\
\hline BM136745 & Alkaline proteinase (serine proteinase) (Trichoderma harzianum) ${ }^{\mathrm{b}}$ & $1.00 \mathrm{E}-32$ \\
\hline BM138487 & Cutinase G-box binding protein (Fusarium solani f. sp. pisi) ${ }^{\mathrm{b}}$ & $7.00 \mathrm{E}-26$ \\
\hline BM138109 & Endo- $\beta$ 1,4-xylanase A (Chaetomium gracile $)^{\mathrm{b}}$ & 4.00E-08 \\
\hline BM136500 & Family F xylanase (Fusarium oxysporum f. sp. lycopersici) ${ }^{\mathrm{b}}$ & $9.00 \mathrm{E}-67$ \\
\hline BM137184 & Hexose transporter protein (Aspergillus parasiticus) & $2.00 \mathrm{E}-34$ \\
\hline BM136589 & Mitochondrial 2-oxodicarboxylate transport protein (Saccharomyces cerevisiae) & $1.00 \mathrm{E}-31$ \\
\hline BM137772 & Mitochondrial elongation factor G-like protein (Saccharomyces cerevisiae) & $2.00 \mathrm{E}-36$ \\
\hline BM135467 & NADP-specific glutamate dehydrogenase (Neurospora crassa) & $2.00 \mathrm{E}-50$ \\
\hline BM135694 & Proteasome component YC1 (Saccharomyces cerevisiae) & $1.00 \mathrm{E}-46$ \\
\hline BM140448 & Proteasome subunit for peptidyl glutamyl peptide hydrolyzing activity (Saccharomyces cerevisiae) & 7.00E-49 \\
\hline BM136376 & Putative transcription factor (Acremonium chrysogenum) & $8.00 \mathrm{E}-23$ \\
\hline BM135219 & Related to CCR4 protein (Neurospora crassa) & $4.00 \mathrm{E}-09$ \\
\hline BM134542 & Trichodiene oxygenase $(\text { Gibberella zeae })^{\mathrm{b}}$ & $5.00 \mathrm{E}-34$ \\
\hline BM135798 & Xylanase (Helminthosporium turcicum) & $2.00 \mathrm{E}-45$ \\
\hline BM134812 & Xylanase 5 protein (Fusarium oxysporum f. sp. lycopersici) ${ }^{\text {b }}$ & $3.00 \mathrm{E}-73$ \\
\hline
\end{tabular}

\footnotetext{
${ }^{\mathrm{a}}$ Functional annotations and corresponding E value for the highest scoring BLASTX hit for fungal sequences that were either not found to be redundant using the phragment assembly program (PHRAP) (minimum match 40, minimum score 80) to 8,727 F. graminearum ESTs generated from three fungal cultures or that produced BLASTN hits to ESTs generated from cDNA libraries associated with fungal pathogenicity.

${ }^{\mathrm{b}}$ Fungal sequences encoding proteins with functions that are likely associated with pathogenesis.
} 
cine max, 127,053 Lycopersicon spp., 122,366 Medicago truncatula, 113,003 Arabidopsis thaliana, 96,359 Zea mays, 91,653 Sorghum spp., 76,336 Oryza sativa, and 73,653 Hordeum spp. ESTs (as of 22 June 2001). As more ESTs generated from different plants, tissues, and growth stages become available, the number of our library-specific genes is likely to decrease. Nevertheless, the fact that these library-specific genes have not been found in dbEST suggests that they are likely candidates for defense-specific expression.

\section{Plant-fungal interaction genes.}

We found 29 genes that had sequence matches in dbEST to ESTs from one of five resistant plant-fungal and one plantsymbiont interactions (Table 4). These genes were grouped into four subsets. The first subset contains seven genes, which were found only in our library and another cDNA library made from type II resistant 'Sumai 3' infected by F. graminearum. These seven genes may be specifically expressed in the wheat $-F$. graminearum interaction. One of these encodes a lectin, which was abundantly expressed (Table 1). Lectins are proteins that specifically bind (or crosslink) carbohydrates; they have been implicated in the response of plants to insect feeding (Dodd and Drickamer 2001; Peumans and Van Damme 1995; Zhu-Salzman et al. 1998).

The other three and possibly more interesting subsets consist of 22 genes that were found in our F. graminearuminfected 'Sumai 3' cDNA library and in one other plantfungal cDNA library. We established that 18 of these 22 genes also were sequenced from cDNA libraries from wheat and barley interactions with the biotrophic pathogens Puccinia triticina and Blumeria (formerly Erysiphe) graminis, respectively. The identification of these 18 genes is consistent with observations that $F$. graminearum acts in a biotrophiclike manner in the initial 48 hai (Bushnell et al. 2000; Kang and Buchenauer 2000a; Pritsch et al. 2000). The exact role of the proteins encoded by these genes in the wheat $-F$. graminearum interaction or in any other plant-fungal interaction is, as yet, unknown. However, it is intriguing that these 18 genes were expressed in two different resistant plant-pathogen interactions and that one of these genes also was expressed in the symbiotic interaction between Medicago truncatula and the arbuscular mycorrhizal fungus Glomus versiforme. We speculate that we have discovered a subset of 22 genes encoding proteins that may participate in the establishment of various plant-fungal interactions.

\section{Concluding remarks.}

Our results underscore the usefulness of comparative bioinformatics as a powerful tool for gene discovery. We identified genes expressed in the wheat $-F$. graminearum interaction that encode proteins associated with plant responses to biotic and abiotic stress and with $F$. graminearum proteins associated with degradation of plant cell walls. In addition, we used comparative bioinformatics to identify sets of genes that have not been associated with plant defense and fungal pathogenicity. These genes warrant further analysis to determine their role in the wheat $-F$. graminearum interaction and in other plantpathogen interactions. As more ESTs from different plantpathogen interactions become available and as existing gene databases increase in size, comparative bioinformatics will be needed to sort through and identify expressed genes that are associated with plant resistance and pathogen virulence. As our EST database expands, we will use comparative bioinformatics to identify expressed genes associated with defense against different wheat pathogens and expressed genes associated with pathogenicity of $F$. graminearum on different host plants.

\section{MATERIALS AND METHODS}

\section{Plant material and $F$. graminearum strain.}

Wheat cv. Sumai 3, known for its type II resistance to FHB, was used (Bai and Shaner 1994; Wilcoxson et al. 1993). Plants were grown in growth chambers as described by Pritsch and associates (2000). The monosporic isolate $3 \mathrm{~A} 31$ of $\mathrm{F}$. graminearum (a gift from R. Dill-Macky, University of Minnesota) was used for the inoculations. The 3A31 isolate was collected from barley in Felton, Minnesota, in July 1995 and grown on Fusarium spp. selective pentachloronitrobenzene (PCNB) agar (Nash and Snyder 1962). Details of the macroconidia preparation for inoculum were previously described (Pritsch et al. 2000).

\section{F. graminearum inoculations and RNA isolations.}

'Sumai 3' spikes were spray inoculated at anthesis (Zadoks stage 65 to 69 ; Zadoks et al. 1974) with a freshly prepared spore suspension of $2 \times 10^{6}$ macroconidia per $\mathrm{ml}$ in $0.04 \%$ (vol/vol) Tween 20 in water. Inoculations were conducted according to Pritsch and associates (2000). Briefly, spray inoculations were performed with an air brush (Model VL; Paasche Airbrush, Harwood Heights, IL, U.S.A.) adjusted to a pressure of $82.8 \mathrm{kPa}$. An average of $500 \mu \mathrm{l}$ of spore suspension was retained on each spike. After inoculation, the plants were placed in a dew chamber set at $21^{\circ} \mathrm{C}, 98 \pm 2 \%$ relative humidity, and continuous light $\left(5.7 \mu \mathrm{E} \mathrm{s}^{-1} \mathrm{~m}^{-2}\right)$. Spikes were sampled at 0,6 , $12,24,36$, and 48 hai for RNA isolations. RNA was isolated according to De Vries and associates (1982). RNA preparations from the six different timepoints were combined in equivalent quantities. The resulting bulked sample contained approximately $2 \mathrm{mg}$ of total RNA. Poly (A) ${ }^{+}$RNA was purified using oligo-dT cellulose columns (MessageMaker Reagent Assembly; Life Technologies, Carlsbad, CA, U.S.A.).

\section{cDNA library preparation.}

Methylmercury hydroxide $(5 \mu \mathrm{g})\left(\mathrm{CH}_{3} \mathrm{HgOH}\right)$-pretreated poly $(\mathrm{A})^{+}$RNA was used as template for reverse transcription using a hybrid oligo(dT) linker-primer (ZAP-cDNA synthesis kit, Stratagene, La Jolla, CA, U.S.A.). The cDNA products were size-selected and inserted into the Uni-ZAP XR vector (Stratagene). Recombinant $\lambda$ DNA-wheat cDNA was packaged with Gigapack III Gold Packaging Extract (Stratagene). The cDNA library was then amplified and stored at $4^{\circ} \mathrm{C}$.

\section{EST sequencing and bioinformatics.}

Sequencing was carried out in two batches. A batch of 89 sequences was processed in the Advanced Genetics Analysis Center (University of Minnesota, St. Paul, U.S.A.) and a larger batch of 4,749 sequences was processed in O. Anderson's laboratory. The cDNA library was plated out on $22 \times 22-\mathrm{cm}$ plates. White colonies were picked and placed into 384-well plates using a Q-Bot (Genetix, Hampshire, UK). Overnight cultures from 384-well plates were transferred into four 96deep-well plates for cell growth and plasmid DNA isolation. Plasmids were prepared using a modified alkaline lysis protocol (Eppendorf, Hamburg, Germany) and eluted in $75 \mu \mathrm{l}$ of molecular biology-grade water. Aliquots were labeled with Big Dye Terminator chemistry (Applied Biosystems, Foster City, CA, U.S.A.) using a thermocycler (MJ Research, Waltham, MA, U.S.A.). The products were precipitated with isopropanol and separated by capillary electrophoresis using an ABI3700 sequencer (Applied Biosystems). Trace files were analyzed using the ABI3700-trained phred program (Ewing et al. 1998; Ewing and Green 1998). Plates with more than 30 clones having sequence reads longer than 300 quality bases (phred score $>20$ ) were passed on for further analysis. Bases at the ends of 
a sequence read with a phred quality score of less than 20 (i.e., the base call error rate higher than 1/100) were trimmed. If over $50 \%$ of the bases in a sequence read had phred quality scores less than 20, then the whole sequence was manually removed. Cross_match (a general-purpose utility based on the Smith-Waterman algorithm for comparing any two sets of DNA sequences and a component of the PHRAP package) was applied to find and mask vector sequences, which then were removed. Sequence editing involved removing undesirable sequences, such as sequence reads less than 100 bases, control sequences, sequences containing exclusively long poly(A) or poly $(\mathrm{T})$, and sequences of rRNA origin. All the ESTs were deposited in dbEST in two batches. The first batch of sequences has accession numbers from BM134271 to BM138704 and from BM140307 to BM140614. The cDNA clones that correspond to these sequences are available through O. Anderson's laboratory. A second batch of sequences has accession numbers from BM259010 to BM259098 and the corresponding cDNA clones are available through G. Muehlbauer's laboratory (University of Minnesota, St. Paul, U.S.A.).

The ESTs that were generated from the three $F$. graminearum culture cDNA libraries were supplied to us with the consent of H. C. Kistler, F. Trail, and J. Xu. These F. graminearum ESTs are available through the U.S. Wheat and Barley Scab Initiative Website link to the Fusarium graminearum EST database at Purdue University. Any information regarding these se- quences and the three $F$. graminearum culture cDNA libraries or requests for cDNA clones should be directed to $\mathrm{H}$. C. Kistler, F. Trail, or J. Xu.

Contigs were assembled using PHRAP (P. Green, University of Washington, Seattle, U.S.A.) with a minimum match of 40 and a minimum score of 80 . The resultant nonredundant sequence set (singletons and contigs) was searched against the nonredundant GenBank protein database using a stand-alone BLAST client. Functions were assigned to ESTs based on the results returned from searches using the BLASTX algorithm. Any ESTs that did not produce a BLASTX hit were considered to have an unknown function. Sequences that produced hits with $\mathrm{E}$ values greater than $10^{-5}$ also were considered to have an unknown function. Sequences that produced hits to proteins with no discernable function were grouped into a miscellaneous category. Sequences giving BLASTX hits to fungal proteins were placed in the fungal gene category. The remaining sequences were placed into one of five broad functional categories: protein synthesis and modification, metabolism, regulatory, structural, and secondary metabolism. These categories were chosen to overcome difficulties with the interpretation of functional annotations. Hits to proteins with a defined metabolic function like those involved in energy, oxygen and redox, lipid, and carbohydrate metabolism were placed in the metabolic category. Membrane-bound, cytoskeleton, and ribosomal proteins were included in the structural category.

Table 4. Nonredundant sequences putatively specifically expressed in plant-fungal interactions ${ }^{\mathrm{a}}$

\begin{tabular}{|c|c|c|c|c|}
\hline Genbank accession no. & BLASTX annotation $^{\mathrm{b}}$ & E value & $\begin{array}{c}\text { No. of } \\
\text { dbEST hits }\end{array}$ & $\begin{array}{l}\text { No. of } \\
\text { ESTs }\end{array}$ \\
\hline \multicolumn{5}{|c|}{ Fusarium head blight of wheat (i) } \\
\hline BM259052 & High-affinity potassium transporter (Phragmites australis) & $2.00 \mathrm{E}-36$ & 2 & 1 \\
\hline BM135003 & Hypothetical protein (Oryza sativa) & $6.00 \mathrm{E}-14$ & 1 & 1 \\
\hline BM138062 & No BLASTX hit & $\ldots$ & 1 & 1 \\
\hline BM137914 & No BLASTX hit & $\ldots$ & 1 & 1 \\
\hline BM137769 & Putative lectin (Hordeum vulgare) & $7.00 \mathrm{E}-15$ & 1 & 14 \\
\hline BM137069 & Putative obtusifoliol 14-alpha demethylase (Arabidopsis thaliana) & $7.00 \mathrm{E}-11$ & 4 & 1 \\
\hline BM140349 & Putative protein phosphatase-2C (Arabidopsis thaliana) & $3.00 \mathrm{E}-46$ & 1 & 1 \\
\hline \multicolumn{5}{|l|}{ Leaf rust of wheat (ii) } \\
\hline BM135357 & Kaurene synthase (Zea mays) (also found in i) & $6.00 \mathrm{E}-46$ & 2 & 1 \\
\hline BM134980 & No BLASTX hit & $\ldots$ & 1 & 1 \\
\hline BM135834 & No BLASTX hit & $\ldots$ & 1 & 1 \\
\hline BM134557 & Putative ABC transporter ATP-binding protein (Oryza sativa) & $3.00 \mathrm{E}-37$ & 1 & 1 \\
\hline \multicolumn{5}{|c|}{ Powdery mildew of barley (iii) } \\
\hline BM137409 & Cytokinin oxidase (Arabidopsis thaliana) & $5.00 \mathrm{E}-48$ & 1 & 1 \\
\hline BM134684 & No BLASTX hit & $\ldots$ & 1 & 1 \\
\hline BM135475 & No BLASTX hit & $\ldots$ & 1 & 1 \\
\hline BM135955 & No BLASTX hit & $\ldots$ & 2 & 1 \\
\hline BM136171 & No BLASTX hit & $\ldots$ & 1 & 1 \\
\hline BM135636 & No BLASTX hit & $\ldots$ & 1 & 1 \\
\hline BM135786 & No BLASTX hit & $\ldots$ & 1 & 1 \\
\hline BM136225 & Putative laccase (Arabidopsis thaliana) & $1.00 \mathrm{E}-18$ & 2 & 1 \\
\hline BM140423 & Putative peptide transporter (Oryza sativa) & $9.00 \mathrm{E}-28$ & 1 & 4 \\
\hline BM134315 & Receptorlike protein kinaselike protein (Arabidopsis thaliana) & $1.00 \mathrm{E}-14$ & 1 & 1 \\
\hline BM136409 & Similar to human mitotic control protein (Oryza sativa) (v) & $6.00 \mathrm{E}-54$ & 2 & 1 \\
\hline BM134609 & Thylakoid assembly protein 4 (Zea mays) & $8.00 \mathrm{E}-18$ & 2 & 1 \\
\hline BM135610 & Tryptophan decarboxylase (Catharanthus roseus) & $8.00 \mathrm{E}-16$ & 1 & 1 \\
\hline BM136081 & Unknown protein (Arabidopsis thaliana) & $9.00 \mathrm{E}-12$ & 4 & 1 \\
\hline \multicolumn{5}{|c|}{ Anthracnose of sorghum (iv) } \\
\hline BM135760 & dnaJ-like protein (Arabidopsis thaliana) & $2.00 \mathrm{E}-27$ & 2 & 1 \\
\hline BM140391 & Kaurene synthase (Zea mays) & $2.00 \mathrm{E}-38$ & 1 & 2 \\
\hline BM137256 & Unknown protein (Arabidopsis thaliana) & $3.00 \mathrm{E}-22$ & 1 & 1 \\
\hline BM135166 & No BLASTX hit & $\ldots$ & 1 & 2 \\
\hline
\end{tabular}

${ }^{\mathrm{a}}$ These nonredundant sequences produced sequence hits to expressed sequence tags (ESTs) from one of six other plant-fungal interaction cDNA libraries. (i) Wheat spikes $24 \mathrm{~h}$ after Fusarium graminearum inoculation; (ii) wheat leaves $24 \mathrm{~h}$ after Puccinia triticina inoculation; (iii) two barley seedling libraries inoculated with Erysiphe graminis; (iv) sorghum leaves (2 weeks old) $48 \mathrm{~h}$ after inoculation with anthracnose; and (v) Medicago truncatulata roots harvested at 10,17, 22,31, and 38 days after inoculation with Glomus versiforme.

${ }^{b}$ The highest scoring BLASTX hit and corresponding E value are listed for each sequence. Where more than one EST is indicated the GenBank accession number corresponds to the most $5^{\prime}$ sequence from that contig.

${ }^{c}$ Number of hits in dbEST using the BLASTN algorithm $\left(P \leq 10^{5}\right)$.

${ }^{\mathrm{d}}$ Number of ESTs in our $F$. graminearum-wheat cDNA library. 
Phenylpropanoid, pathogenesis-related, and flavonoid and lignin biosynthetic proteins are examples of proteins encoded by secondary metabolism genes. MAP kinases, transcription factors, and proteins that are associated with development or cell cycle control were considered to be proteins encoded by regulatory genes. Translation factors, tRNA ligases, and protein kinases and hydrolases are examples of proteins encoded by protein synthesis and modification genes. Nonredundant sequences with the same or very similar BLASTX annotations, but that did not group into a contig, were considered to encode different protein types. This is a simplification because it is possible that two ESTs may be derived from nonoverlapping regions of the same gene transcript.

The dbEST database is a division of GenBank containing sequence data and other information on ESTs from a number of organisms. To identify putative library-specific ESTs, searches of the dbEST nucleotide database, using the BLASTN and TBLASTX algorithms, were conducted. Only sequence hits with $\mathrm{E}$ values $\leq 10^{-5}$ were considered matches. Searches of dbEST using the BLASTN or TBLASTX algorithms are based only on nucleotide or amino acid sequence similarity and give no functional information. In contrast, the nonredundant GenBank protein database contains functional annotation for proteins and can be searched for amino acid sequence similarity using the BLASTX algorithm. Therefore, it is possible to find an EST with a functional annotation and no dbEST hit.

\section{ACKNOWLEDGMENTS}

We thank H. C. Kistler and W. R. Bushnell (USDA-ARS, St. Paul, MN, U.S.A.) for critical reading of the manuscript; C. Vance and S. Miller (USDA-ARS, St. Paul) for technical help with the cDNA library preparation; O. Anderson (USDA-ARS, Albany, CA, U.S.A.) for conducting the sequencing of the ESTs; and E. Retzel and R. Staggs (University of Minnesota) for bioinformatics support. This work was supported by grants to G. J. Muehlbauer from the Minnesota State Legislative Scab Initiative and the U.S. Wheat and Barley Scab Initiative.

\section{LITERATURE CITED}

Ali, Z. M., Armugam, S., and Lazan, H. 1995. beta-Galactosidase and its significance in ripening mango fruit. Phytochemistry 38:1109-1114.

Arumuganathan, K., and Earle, E. D. 1991. Nuclear DNA content of some important plant species. Plant Mol. Biol. Rep. 9:208-218.

Audic, S., and Claverie, J. M. 1997. The significance of digital gene expression profiles. Genome Res. 7:986-995.

Bai, G. H., and Shaner, G. 1994. Scab of wheat: Prospect for control. Plant Dis. 78:760-766.

Bent, A. F. 1996. Plant disease resistance genes: Function meets structure. Plant Cell 8:1757-1771.

Bowles, J. D. 1990. Defense-related protein in higher plants. Annu. Rev. Biochem. 59:873-907.

Bushnell, W. R., Skadsen, R. W., Lewandowski, S., Seeland, T., and Krueger, D. E. 2000. Development of Fusarium graminearum in detached segments of barley leaves. (Abstr.) Natl. Fusarium Head Blight Forum: 129 .

Byth, H. A., Kuun, K. G., and Bornman, L. 2001. Virulence-dependent induction of Hsp70/Hsc70 in tomato by Ralstonia solanacearum. Plant Physiol. Biochem. 39:697-705.

Carlile, A. J., Bindschedler, L. V., Bailey, A. M., Bowyer, P., Clarkson, J. M., and Cooper R. M. 2000. Characterization of SNP1, a cell walldegrading trypsin, produced during infection by Stagonospora nodorum. Mol. Plant-Microbe Interact. 13:538-550.

Carpita, N., and Gibeaut, D. 1993. Structural models of primary cell walls in flowering plants: Consistency of molecular structure with the physical properties of the walls during growth. Plant J. 3:1-30.

Crawford, M. S., and Kolattukudy, P. E. 1987. Pectate lyase from Fusarium solani $\mathrm{f}$. sp. pisi: Purification, characterization, in vitro translation of the mRNA, and involvement in pathogenicity. Arch. Biochem. Biophys. 258:196-205.

Cutt, J. R., and Klessig, D. F. 1992. Pathogenesis-related proteins. Pages 209-243 in: Genes Involved in Plant Defense. T. Boller and F. Meins, eds. Springer-Verlag, Vienna.

D’Agostaro, G. A. F., Zingoni, A., Moritz, R. L., Simpson, R. J., Schachter, H., and Bendiak, B. 1995. Molecular cloning and expression of cDNA encoding the rat UDP-N-acetylglucosamine-6-D-mannoside -1,2-N-acetylglucosaminyltransferase II. J. Biol. Chem. 270:15211-15221.

Desjardins, A. E., and Hohn, T. M. 1997. Mycotoxins in plant pathogenesis. Mol. Plant-Microbe Interact. 10:147-152.

Desjardins, A. E., Proctor, R. H., Bai, G., McCormick, S. P., Shaner, G., Buechley, G., and Hohn, T. 1996. Reduced virulence of tricothecenenonproducing mutants of Gibberella zeae in wheat field tests. Mol. Plant-Microbe Interact. 9:775-781.

De Vries, S. C., Springer, J., and Wessels, J. G. H. 1982. Diversity of abundant mRNA sequences and patterns of protein synthesis in etiolated and greened pea seedlings. Planta 156:129-135.

Dixon, R. A., and Lamb, C. J. 1990. Molecular communication in interactions between plants and microbial pathogens. Annu. Rev. Plant Physiol. Plant Mol. Biol. 41:339-367.

Dixon, R. A., and Paiva, N. L. 1995. Stress-induced phenylpropanoid metabolism. Plant Cell 7:1085-1097.

Dodd, R. B., and Drickamer, K. 2001. Lectin-like proteins in model organisms: Implications for evolution of carbohydrate-binding activity. Glycobiology 11:71R-79R.

Ewing, B., and Green, P. 1998. Base-calling of automated sequencer traces using phred. II. Error probabilities. Genome Res. 8:186-194.

Ewing, B., Hillier, L., Wendl, M. C., and Green, P. 1998. Base-calling of automated sequencer traces using phred. I. Accuracy assessment. Genome Res. 8:175-185.

Ewing, R. M., Kahla, A. B., Poirot, O., Lopez, F., Audic, S., and Claverie, J. M. 1999. Large-scale statistical analyses of rice ESTs reveal correlated patterns of gene expression. Genome Res. 9:950-959.

Giesbert, S., Lepping, H. Tenberge, K. B., and Tudzynski, P. 1998. The xylanolytic system of Claviceps purpurea: Cytological evidence for secretion of xylanases in infected rye tissue and molecular characterization of two xylanase genes. Phytopathology 88:1020-1030.

Gyorgyey, J., Vaubert, D., Jimenez-Zurdo, J. I., Charon, C., Troussard, L., Kondorosi, A., and Kondorosi, E. 2000. Analysis of Medicago truncatula nodule expressed sequence tags. Mol. Plant-Microbe Interact. 13:62-71

Hammond-Kosak, K. E., and Jones, J. D. G. 1996. Resistance-gene dependent plant defense responses. Plant Cell 8:1773-1791.

Hawkins, A. R., Gurr, S. J., Montague, P., and Kinghorn, J. R. 1989. Nucleotide sequence and regulation of expression of the Aspergillus nidulans gdhA gene encoding NADP dependent glutamate dehydrogenase. Mol. Gen. Genet. 218:105-111.

Heiler, S., Mendgen, K., and Deising, H. 1993. Cellulolytic enzymes of the obligately biotrophic rust fungus Uromyces viciae-fabae are regulated differentiation-specifically. Mycol. Res. 97:77-85.

Kang, Z., and Buchenauer, H. 1999. Immunocytochemical localization of fusarium toxins in infected wheat spikes by Fusarium culmorum. Physiol. Mol. Plant Pathol. 55:275-288.

Kang, Z., and Buchenauer, H. 2000a. Cytology and ultrastructure of the infection of wheat spikes by Fusarium culmorum. Mycol. Res. 104:1083-1093.

Kang, Z., and Buchenauer, H. 2000b. Ultrastructural and cytochemical studies on cellulose, xylan and pectin degradation in wheat spikes infected by Fusarium graminearum. J. Phytopathol. 148:263-275.

Kang, Z., and Buchenauer, H. 2000c. Ultrastructural and immunocytochemical investigation of pathogen development and host responses in resistant and susceptible wheat spikes infected by Fusarium culmorum. Physiol. Mol. Plant Pathol. 57:255-268.

Keon, J., Bailey, A., and Hargreaves, J. 2000. A group of expressed cDNA sequences from the wheat leaf blotch pathogen, Mycosphaerella graminicola (Septoria tritici). Fungal Genet. Biol. 29:118-133.

Li, D., and Kolattukudy, P. E. 1997. Cloning of cutinase transcription factor 1 , a transactivating protein containing $\mathrm{Cys}_{6} \mathrm{Zn}_{2}$ binuclear cluster DNA-binding motif. J. Biol. Chem. 272:12462-12467.

Li, W. L., Faris, J. D., Muthukrishnan, S., Liu, D. J., Chen, P. D., and Gill, B. S. 2001. Isolation and characterization of novel cDNA clones of acidic chitinases and $\beta$-1,3-glucanases from wheat spikes infected by Fusarium graminearum. Theor. Appl. Genet. 102:353-362.

Malvar, T., Biron, R. W., Kaback, D. B., and Denis, C. L. 1992. The CCR4 protein from Saccharomyces cerevisiae contains a leucine-rich repeat region which is required for its control of $\mathrm{ADH} 2$ gene expression. Genetics 132:951-962.

McMullen, M. P., Jones, R., and Gallenberg, D. 1997a. Scab of wheat and barley: A re-emerging disease of devastating impact. Plant Dis. 81:1340-1348.

McMullen, M. P., Schatz, B., Stover, R., and Gregoire, T. 1997b. Studies of fungicide, application timing, and application technologies to reduce Fusarium head blight and deoxynivalenol. Cereal Res. Comm. 25:779- 
780

Mekhedov, S., de Ilarduya, O. M., and Ohlrogge, J. 2000. Toward a functional catalog of the plant genome. A survey of genes for lipid biosynthesis. Plant Physiol. 122: 389-401.

Michelmore, R. M. 2000. Genomic approaches to plant disease resistance. Curr. Opin. Plant Biol. 3:125-131.

Miedaner, T. 1997. Breeding wheat and rye for resistance to Fusarium diseases. Plant Breed. 116:201-220.

Miller, J. D., and Ewen, M. A. 1997. Toxic effects of deoxynivalenol on ribosomes and tissues of the spring wheat cultivars Frontana and Casavant. Nat. Toxins 5:234-237.

Nash, S. M., and Snyder, W. C. 1962. Quantitative estimations by plate counts of propagules of the bean root rot Fusarium in field soils. Phytopathology 52:567-572.

Parry, D. W., Jenkinson, P., and McLeod, L. 1995. Fusarium ear blight (scab) in small grain cereals-a review. Plant Pathol. 44:207-238.

Peumans, W. J., and Van Damme, E. J. 1995. Lectins as plant defense proteins. Plant Physiol. 109:347-352.

Pritsch, C., Muehlbauer, G. J., Bushnell, W. R., Somers, D. A., and Vance, C. P. 2000. Fungal development and induction of defense response genes during early infection of wheat spikes by Fusarium graminearum. Mol. Plant-Microbe Interact. 13:159-169.

Pritsch, C., Vance, C. P., Bushnell, W. R., Somers, D. A., Hohn, T. M., and Muehlbauer, G. J. 2001. Systemic expression of defense response genes in wheat spikes as a response to Fusarium graminearum infection. Physiol. Mol. Plant Pathol. 58:1-12.

Proctor, R. H., Hohn, T. M., and. McCormick, S. P. 1995. Reduced virulence of Gibberella zeae caused by disruption of a trichothecene toxin biosynthetic gene. Mol. Plant-Microbe Interact. 8:593-601.

Qutob, D., Hraber, P. T., Sobral, B. W. S., and Gijzen, M. 2000. Comparative analysis of expressed sequences in Phytophthora sojae. Plant Physiol. 123:243-253.

Rafalski, J. A., Hanafey, M., Miao, G. H., Ching, A., Lee, J. M., Dolan, M., and Tingey, S. 1998. New experimental and computational approaches to the analysis of gene expression. Acta Biochim. Pol. 45:929934

Ristic, Z., Yang, G. P., Martin, B., and Fullerton, S. 1998. Evidence of association between specific heat-shock protein(s) and the drought and heat tolerance phenotype in maize. J. Plant Physiol. 153:497-505.

Sabehat, A., Weiss, D., and Lurie, S. 1998. Heat-shock proteins and crosstolerance in plants. Physiol. Plant. 103:437-441.

Schenk, P. M., Kazan, K., Wilson, I, Anderson, J. P., Richmond, T. Somerville, S. C., and Manners, J. 2000. Coordinated plant defense responses in Arabidopsis revealed by microarray analysis. Proc. Natl. Acad. Sci. U.S.A. 97:11655-11660.

Schroeder, H. W., and Christensen, J. J. 1963. Factors affecting resistance of wheat scab caused by Gibberella zeae. Phytopathology 53:831-838.

Shifrin, V. I., and Anderson, P. 1999. Trichothecene mycotoxins trigger a ribotoxic stress response that activates c-Jun N-terminal kinase and p38 mitogen-activated protein kinase and induces apoptosis. J. Biol. Chem. 274:13985-13992.

Silva, A. M. S., Weidenborner, M., and Cavaleiro, J. A. S. 1998. Growth control of different Fusarium species by selected flavones and flavonoid mixtures. Mycol. Res. 102:638-640.

Skadhauge, B., Thomsen, K. K., and von Wettstein, D. 1997. The role of the barley testa layer and its flavonoid content in resistance to Fusarium infections. Hereditas 126:147-160.

Snijders, C. H. A., and Krechting, C. F. 1992. Inhibition of deoxynivalenol translocation and fungal colonization in Fusarium head blight resistant wheat. Can. J. Bot. 70:1570-1576.

Somssich, I. E., and Hahlbrock, K. 1998. Pathogen defence in plants-a paradigm of biological complexity. Trends Plant Sci. 3:86-90.

Sreedhar, L., Kobayashi, D. Y., Bunting, T. E., Hillman, B. I., and Belanger, F. C. 1999. Fungal proteinase expression in the interaction of the plant pathogen Magnaporthe poae with its host. Gene 235:121-129.

Sung, D. Y., Vierling, E., and Guy, C. L. 2001. Comprehensive expression profile analysis of the Arabidopsis Hsp70 gene family. Plant Physiol. 126:789-800.

Sutton, J. C. 1982. Epidemiology of wheat head blight and maize ear rot caused by Fusarium graminearum. Trans. Br. Mycol. Soc. 70:187-192.

ten Have, A., Mulder, W., Visser, J., and van Kan, J. A. L. 1998. The endopolygalacturonase gene Bcpg1 is required for full virulence of Botrytis cinerea. Mol. Plant-Microbe Interact. 10:1009-1016.

Torii, K. U. 2000. Receptor kinase activation and signal transduction in plants: An emerging picture. Curr. Opin. Plant Biol. 3:361-367.

Trapp, S. C., Hohn, T. M., McCormick, S., and Jarvis, B. B. 1998. Characterization of the gene cluster for biosynthesis of macrocyclic trichothecenes in Myrothecium roridum. Mol. Gen. Genet. 257:421-32.

Tuite, J., Shaner, G., and Everson, R. J. 1990. Wheat scab in soft red winter wheat in Indiana in 1986 and its relation to some quality measurements. Plant Dis. 74:959-962.

Vaghchhipawala, Z., Bassuner, R., Clayton, K., Lewers, K., Shoemaker, R., and Mackenzie, S. 2001. Modulations in gene expression and mapping of genes associated with cyst nematode infection of soybean. Mol. Plant-Microbe Interact. 14:42-54.

van der Biezen, E. A., and Jones, J. D. G. 1998. Plant disease-resistance proteins and the gene-for-gene concept. Trends Biochem. Sci. 23:454 456.

Wang, Y. Z., and Miller, J. D. 1988. Screening techniques and sources of resistance to Fusarium head blight. Pages 239-250 in: Wheat Production Constraints in Tropical Environments. A. R. Klatt, ed. CYMMIT, Lisboa, Mexico.

Waugh, M., Hraber, P., Weller, J., Wu, Y., Chen, G., Inman, J, Kiphart, D., and Sobral, B. 2000. The Phythophthora genome initiative database: Informatics and analysis for distributed pathogenic research. Nucleic Acids Res. 28:87-90

White, J. A., Todd, J., Newman, T., Focks, N., Girke, T., de Ilarduya, O. M., Jaworski, J. G., Ohlrogge, J. B., and Benning, C. 2000. A new set of Arabidopsis expressed sequence tags from developing seeds. The metabolic pathway from carbohydrates to seed oil. Plant Physiol. 124:15821594

Wilcoxson, R. D., Bekele, G. T., and Etebarian, H. R. 1993. Fusarium head blight resistance in spring wheat cultivars. Plant Dis. 76:658-661.

Yamamoto, K., and Sasaki, T. 1997. Large-scale EST sequencing in rice. Plant Mol. Biol. 35:135-144.

Yang, Y., Shah, J., and Klessig, D. F. 1997. Signal perception and transduction in plant defense responses. Genes Dev. 11:1621-1639.

Yu, J., Chang, P., Bhatnagar, D., and Cleveland, T. E. 2000. Cloning of a sugar utilization gene cluster in Aspergillus parasiticus. Biochim. Biophys. Acta 1493:211-214.

Zadoks, J. C., Chang, T. T., and Konzak, C. F. 1974. A decimal code for the growth stages of cereals. Weed Res. 14:415-421.

Zhu-Salzman, K., Shade, R. E., Koiwa, H., Salzman, R. A., Narasimhan, M., Bressan, R. A., Hasegawa, P. M., and Murdock, L. L. 1998. Carbohydrate binding and resistance to proteolysis control insecticidal activity of Griffonia simplicifolia lectin II. Proc. Natl. Acad. Sci. U.S.A 95:15123-15128

\section{AUTHOR-RECOMMENDED INTERNET RESOURCES}

U.S. Wheat and Barley Scab Initiative Web site: http://www.scabusa.org/ 